\title{
ENGINEERING STUDIES ON SCALPER ATTACHING TO SUGAR BEET DEFOLIATOR
}

\author{
Salim R. G. * and Hanan M. El-Shal ${ }^{* *}$
}

\begin{abstract}
Defoliating sugar beets without removing the crown can increase storage quality. Because the crown has lower sucrose and more impurities than the body of the sugar beet, removing the crown with knives (scalping) can result in higher sucrose per delivered ton for the producer, that increase the benefit of cultivating area. The main objectives of this study were to evaluate the performance using scalper attached of sugar beet defoliator for cleaning and scalping of the beet heads by rotating blade discs are routed across the head near the ground. Based on the forward movement during driving, the head are cut off cleanly. It is hydraulically driven. Measuring indicators were tested for the defoliator (Grimme BM300) at the tested forward speed $(\mathrm{m} / \mathrm{s})$, type of scalper (connected of scalper and pot, separately scalper) and scalper knife) and type of caliper (rubber track, steel track and steel hollow). It was found that using the tested scalper with steel hollow caliper and separately disk razor hydraulically driven under forward speed of $5.2 \mathrm{~km} / \mathrm{h}$ gave the best results in all treatments. Therefore it is advisable to use the attached scalper that showed the best results for factories of sugar beet comparing the topping of sugar beet without scalper that raising the sucrose ratio and gave the good benefit. Also, the possibility of utilizing was studied under the Egyptian new reclaimed land and to suit large holding farms of investment companies using available facilities on farms. Field experiments were carried out to evaluate the performance of scalper at different forward speed, type of scalper and type of caliper. Scalping efficiency, yield of sugar beet, sugar ratio, power required and the cost of scalping operation were therefore studied.
\end{abstract}

KEYWORDS: Scalper, Defoliator, Crown, Blade disc , Disk razor

\footnotetext{
" Researcher, Agric. Eng. Res. Inst.(AEnRI),Cairo, Egypt. ** Lecturer, Agric. Eng. Dept., Fac. of Agric., Zagazig Univ., Egypt.
} 


\section{INTRODUCTION}

$\mathrm{M}$ any efforts have been exerted for increasing sugar production to overcome the gap between the people consumption and production. It has been recommended to increase beet production area because of the limitation of water sources required for increasing sugar cane production area. Mechanical sugar beet harvesters are not common in Egypt, and manual methods are exhaustive, and impractical. Sugar beet harvesting is carried out in Delta of Egypt manually by hand digging, pulling the roots out by shovel and hoe or by using a chisel plow and collecting the roots manually. Recently in the new reclaimed land the sugar beet harvesting process achieved completely by mechanization. Cole and Seiler (1996) indicated that sugar beets are normally flailed and scalped before harvesting. The purpose of scalping is to remove a portion of the crown, which is the area above the lowest leaf scar. Crown material is higher in impurities and lower in sucrose relative to the main body of the sugar beet root. More sugar per acre can be recovered from beets which are only flailed before harvesting .This increase can come about for several reasons: sugar can be extracted from the crown material, respiration losses during storage would be reduced without cutting the crown, and the amount of root would be reduced by not exposing the most susceptible tissue, the center portion of the crown. farmers removing only about $20 \%$ of the crown material by topping, which reduced tonnage by about $5 \%$. Removal of all the crown material by hand resulted in about $1.2 \%$ increase in sucrose and a $7.1 \%$ reduction in nitrate grade. Sugar beet crown material accounted for $20.5 \%$ of the tonnage delivered to the factory. Kromer $\boldsymbol{e t}$, al. (1998) found that the harvesters today have field capacities from 40 to $130 \mathrm{Mg} / \mathrm{h}$, tank capacities from 5.5 (2-row) to $26 \mathrm{t}$ (6-row) and average harvesting qualities of $5.8 \%$ dirt tare, $1.9 \%$ total mass loss and $75.1 \%$ acceptable topping. Jaggard $\boldsymbol{e t}$ al, (1999) mentioned that scalped beets had about $7.7 \%$ yield loss to scalping and had $0.14 \%$ increase in sucrose content. Non-scalped sugar beets had significantly greater sodium and amino-N contents, resulting in greater sucrose loss to molasses. Also they added that crown tissue has lower sucrose and greater impurities than root tissue. Because the crown has lower sucrose and more impurities 
than the body of the sugar beet, removing the crown resulted in higher sucrose per delivered $\mathrm{Mg}$ for the producer, but will increase the spoilage in the pile. The crown in today's sugar beet varieties is a smaller proportion of the total beet weight but the distribution of sucrose and impurities have not changed. Abd- Rabou (2004) concluded that decreasing forward speed tended to decrease total damaged roots. It is clear that, increasing forward speed from 0.55 to $1.06 \mathrm{~m} / \mathrm{s}$ tends to increase the total damaged root from 4.51 to $5.4 \%$. The highest value of the total damaged roots of $6.2 \%$ was obtained at forward speed of 1.6 $\mathrm{m} / \mathrm{s}$, the lowest value of the total damaged of $3.4 \%$ was obtained at forward speed of $0.55 \mathrm{~m} / \mathrm{s}$. Grimme (2009) mentioned that scalped one centimeter from the beet neck decreases the yield from 5 to $7 \%$ and increases the sugar ratio of 2 to $3 \%$ El-Shabrawy et al. (2014) showed that increasing forward speed resulted in decreasing topped beets percentage. Also they mentioned that, with the two rubber flails shaft and attached disk scalper un-topped has a direct proportional with forward speed. The un-topped beets percentage was lower at using disc scalper. Therefore, the main objective of the present investigation is to choose a suitable mechanism for scalping sugar beet roots. To study the possibility of utilizing it under the Egyptian new reclaimed land and to suit large holding farms of investment companies by using the available power tiller at these farms. Field experiments were carried out to evaluate the performance of scalper at different forward speeds, type of scalper and type of caliper. Topping efficiency, the production, sugar ratio, power requirements and the cost of scalping operation were therefore studied.

\section{MATERIAL AND METHODS}

The field experiments were carried out in new reclaimed land under center pivot irrigation system in Al- Nouran advanced company in Salihia Sector, Al-Sharkia Governorate to defoliate sugar beet in a large holding area (pivots) and evaluate machine performance during the mowing operation for the first time in Egypt. The experimental crop of the present study was sugar beet monogermel (Esperanza). The chosen variety was planted in an area of about 600 feddans. Measuring indicators were tested for the defoliator (BM 300) at the tested forward speed $(\mathrm{m} / \mathrm{s})$, type of scalper (Ts) and type of caliper (Tc) for sugar beet. 
$\underline{\text { A-Materials }}$

Machine use

Table (1) Technical data of the used defoliators (BM300)

\begin{tabular}{|c|c|}
\hline & BM300 \\
\hline Length & $5,600 \mathrm{~mm}(6,700 \mathrm{~mm} *)$ \\
\hline Width & $3,600 \mathrm{~mm}$ \\
\hline Height & $1,300 \mathrm{~mm}$ \\
\hline Mass & $2,300 \mathrm{~kg}(2,700 \mathrm{~kg} *)$ \\
\hline Row width & Adjustable between 45 and $56 \mathrm{~cm}$ \\
\hline Flail shaft & $\begin{array}{l}\text { Continuous flail shaft with spirally arranged steel } \\
\text { flails }\end{array}$ \\
\hline 1st cleaning shaft & $\begin{array}{l}\text { Rubber flails above beet row, row width } \\
\text { mechanically and steplessly adjustable; }\end{array}$ \\
\hline 2nd cleaning shaft & $\begin{array}{l}\text { Rubber flails above beet row, row width } \\
\text { mechanically and steplessly adjustable, }\end{array}$ \\
\hline Depth setting & $\begin{array}{l}\text { Lifting cylinder with spindle adjustable end stop in } \\
\text { front, tool-free adjustment of rear control wheels }\end{array}$ \\
\hline Tires & $4 \times 7.5-20$ TR 15 AS \\
\hline Operating/Setting & $\begin{array}{l}1 \text { double acting independent controller }(+1 \text { single } \\
\text { acting controller with pressure-free return*) }\end{array}$ \\
\hline Drive & $\begin{array}{l}\text { Mechanically: PTO-shaft 1,000 rpm with } \\
\text { freewheeling }\end{array}$ \\
\hline Required power & $\begin{array}{l}\text { At least: } 60 \mathrm{~kW} / 82 \mathrm{HP} \text {, Recommended: } 90 \mathrm{KW} / 120 \\
\mathrm{HP}\end{array}$ \\
\hline
\end{tabular}

\section{-Measuring instruments:}

1- Hand peeler: to remove a slice approximately $1.0 \mathrm{~mm}$ thick for damage classification.

2- Balance: to measure the mass of roots obtained from the plots of replicates an ordinary balance (accuracy of $1.0 \mathrm{~g}$ ).

3- Vernier caliper: to measure the dimension of roots size with accuracy of $1 / 20 \mathrm{~mm}$.

4- Steel tape: to measure the length of the replicate tracks and both length and width of plots.

5- Fuel consumption apparatus: the fuel consumed during the harvesting operation was measured by using a fuel consumption apparatus. Its 
capacity is of about $750 \mathrm{ml}$. It has a reading ruler divided into 15 divisions. Each of the division is reading $50 \mathrm{ml}$.

6- Tachometer: to measure the rotation speed of shafts.

\section{-The field experiments:}

The field experiments were carried out in an area pivot (each one pivot area 150 feddans). The dimensions of every one pivot of about one $\mathrm{km}$ diameter and $3 \mathrm{~km}$ circumstance. Sugar beet seeds variety of (Esperanza monogerme) was mechanically planted.

\section{B-Methods:}

The following parameters were studied to evaluate the performance of the scalper with three replicates for each treatment as follows:.

1-Average four forward speeds of 4.5, 5.2, 6 and $7.1 \mathrm{~km} / \mathrm{h}$.

2- Three types of scalper were used:

a- Connected of scalper and pot, Cp. , b - Separately scalper, Sp., c-Scalper knife, Sk.

3-Three types of caliper:

a- Rubber track, Rt., b- Steel track, St. and c- Steel hollow, Sh.

The row width was adjusted at $45 \mathrm{~cm}$; the spaces between seeds in row were adjusted at $20 \mathrm{~cm}$ and the depth at $3 \mathrm{~cm}$ for sugar beet planting.

\section{Measurements:}

\section{1- Scalping efficiency ( $\%$ )}

The scalping efficiency (\%) was evaluated by observing the sugar beet scalper. During the experimental work, the performance of scalper assessed by taking randomly selected $30 \mathrm{~m}$ of work length, lifting the beet and collecting the tops. So scalping efficiency can be estimated easily. The percentage of the items, which are used to control topper performance, can be calculated as the following:

$$
\begin{aligned}
& \text { Scalped beet } \cdot\langle \%\rangle=\frac{\text { No. of scalped beet }}{\text { Total No. of beet } \cdot \text { in } \cdot \text { sample }} \times 100 \\
& \text { Un } \cdot \text { scalped } \cdot \text { beet } \cdot\langle \%\rangle=100-(\text { scalped beet, } \% \\
& \text { Scalping efficiency }(\%)=(100-\text { non scalped beet }) \times 100
\end{aligned}
$$




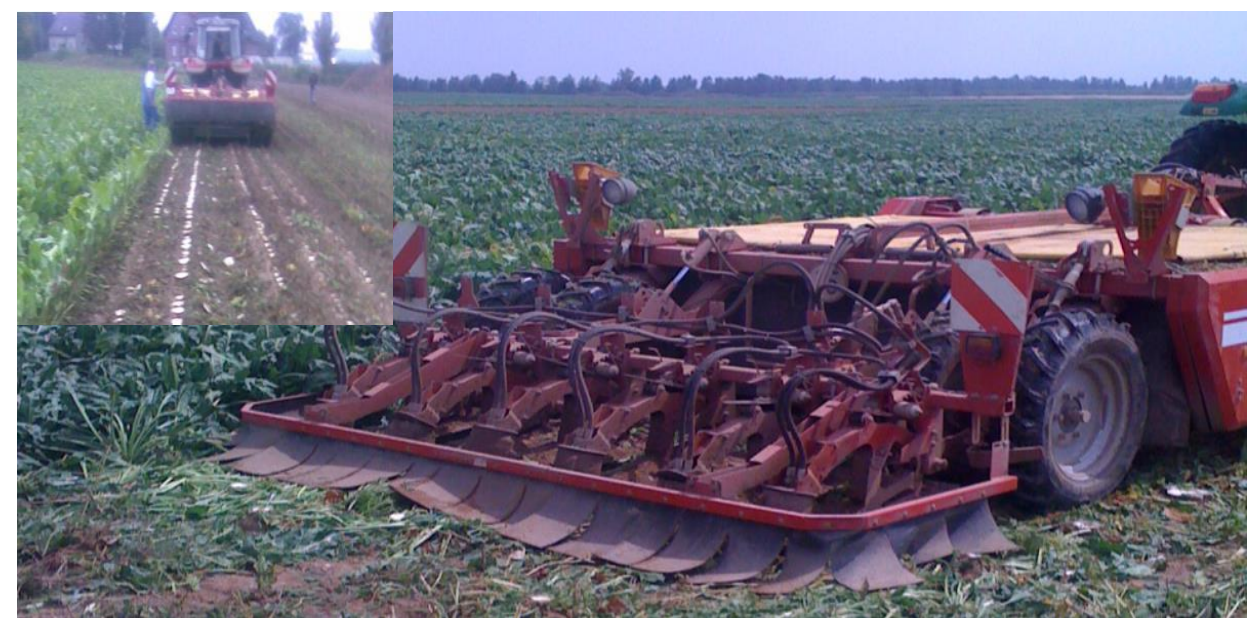

Fig.(1):The BM 300 Grimme defoliator machine with rear attached scalper.

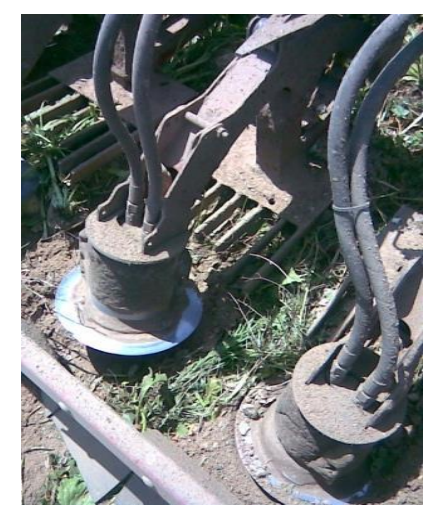

(A)

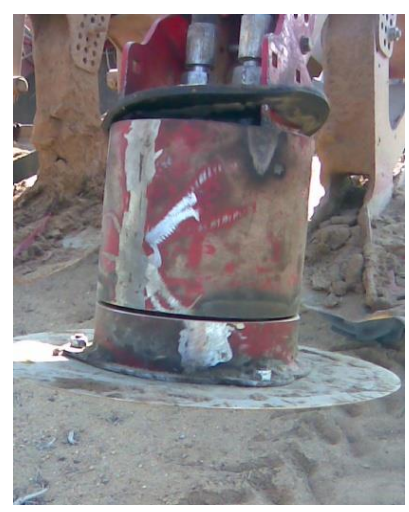

(B)

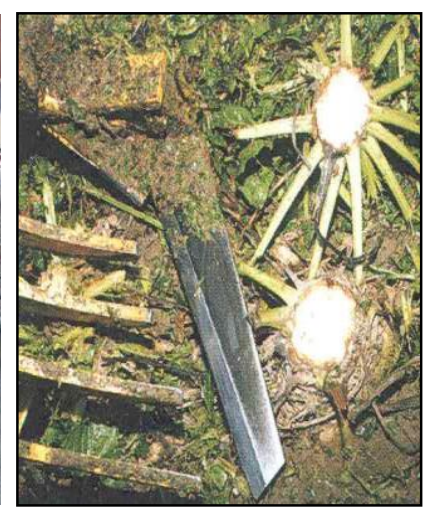

(C)

Fig. (2): Types of scalper: A- scalper connected by pot, B- separately razor disc, $\mathrm{C}$ - scalper knives.

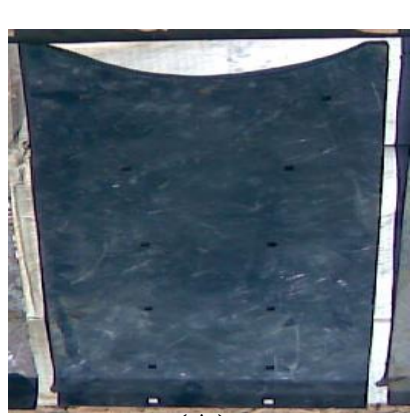

(A)

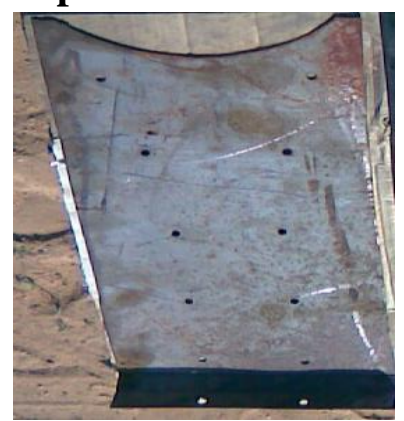

(B)

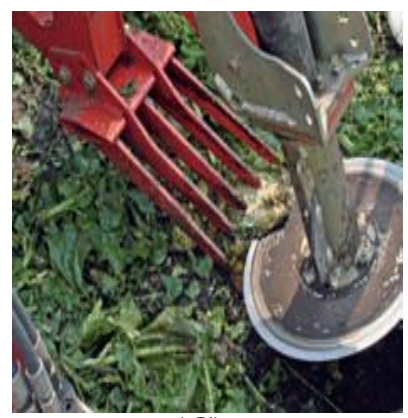

(C)

Fig. (3): Types of caliper: A- rubber track, B- steel track ,C-steel hollow. 


\section{Root yield}

The average values of root yield were calculated after harvesting, ten plants were taken randomly from two inner ridges of each plot to estimate; root length, root diameter and root fresh weight (g/plant), then the root yield calculated by following equation:

$$
Y=\frac{4.2 \times M}{A},(M g / \text { fed } .) .
$$

Where:

$\mathrm{Y}=$ root yield, $\mathrm{Mg} / \mathrm{fed}$.

$\mathrm{M}=$ mass of lifted root, $\mathrm{kg}$.

$\mathrm{A}=$ harvested area, $\mathrm{m}^{2}$.

\section{Sugar yield:}

Sugar yield calculated by multiplying root yield by sucrose percentage (\%) that estimated according to the methods of the analysis conducted by the staff of laboratory of Belkas Sugar Factory, Dakhlia Sugar Company.

\section{4- Fuel consumption}

Fuel consumption was determined by using a fuel consumption apparatus its capacity of about $750 \mathrm{ml}$. It has a reading scale divided into 15 sections with accuracy of $50 \mathrm{ml}$. The rate of fuel consumption was calculated as quantity per unit time, as shown in the following equation:

$$
\text { C.F. }=\frac{f}{t} \times 3.6,(L / h)
$$

Where:

C.F. $=$ Fuel consumption, $\mathrm{L} / \mathrm{h}$

$\mathrm{f}=$ volume of fuel consumption, $\mathrm{cm}^{3}$

$\mathrm{t}=$ time, $\mathrm{s}$.

Also, The specific fuel consumption (S.F.C.) calculated by using the following equation:

$$
\text { S.F.C }=\frac{\text { Fuel consumption }}{\text { Power consumed }},(L / k W . h)
$$

\section{The statistical analysis:}

The experiments were arranged in split plot design with three replicates by using Minitab software (Regression analysis and ANOVA). The analysis of variance was done to investigate the significance of the studied variables. Also, the best fit multiple linear regression equations and Regression Coefficient, $\mathrm{R}^{2}$ were developed for each variable. 


\section{RESULTS AND DISSCUSSION}

\section{Effect of scalper and caliper types on the scalping efficiency at}

\section{different forward speeds}

Fig. (3) show the percentage of scalping efficiency for the scalper at the tested forward speed, type of scalper and type of caliper for sugar beet. The achieved results revealed that both type of scalper and type of caliper for sugar beet roots scalper affected deeply the scalping efficiency at constant forward speed. The results showed that increasing forward speed resulted in decreasing scalping efficiency. The overall data mentioned that, at the separately scalper type and attached caliper (steel hollow) under forward speeds of 4.5, 5.2, 6 and $7.1 \mathrm{~km} / \mathrm{h}$, the average of scalping efficiency were 98.3, 97.2, 96 and 95.1, respectively. As illustrated in Fig.(3), it was clear that the scalping efficiency was higher at $\mathrm{Sp}$ than $\mathrm{Cp}$ and $\mathrm{Sk}$ attached disc scalper. The highest value of the scalping efficiency $98.3 \%$ at $\mathrm{Sp}$ and $\mathrm{Sh}$ was obtained under forward speed of $4.5 \mathrm{~km} / \mathrm{h}$ while the lowest value of the scalping efficiency under $\mathrm{Cp}$ and Rt was $93.1 \%$ under forward speed of $7.1 \mathrm{~km} / \mathrm{h}$. The analyzed data showed that there was a significant effect for using separately disc razor and steel hollow caliper $(\mathrm{p}<0.01)$ under the same conditions of forward speed. From mentioned data, there is a direct proportional between the scalping efficiency and forward speed and the optimum results achieved at separately disc razor and steel hollow caliper, this may be due to the increase of tractor forward speed will decrease the scalped crown by using the separately disc razor at tilt angle 10 degree led for cutting the crowns easier than the others connected disk razor and scalper knife while the steel hollow fixed on the top of ridge more than the other two types rubber track and steel track that skidding from the top of ridge led to leaking the calibration of cut depth caused decreasing in the crowns topper.

\section{Effect of scalper and caliper types on root yield and sucrose percentage at different forward speeds}

Fig. (4) showed that total root yield decrease linearly with decreasing of tractor forward speed, but they increase linearly by using separately scalper steel hollow. Also, increasing tractor forward speed from 4.5 to $7.1 \mathrm{~km} / \mathrm{h}$ at separately scalper (Sp) and steel hollow (Sh) increased the 
root yield from 17.6 to18.9 $\mathrm{Mg} / \mathrm{fed}$. respectively. This may be due to increasing forward speed with separately scalper and steel hollow led to decreasing scalped of crowns that resulting increment of yield and decrement of sugar ratio, that causing give the smallest of benefit. Also, fig. (5) illustrate that higher sugar yield achieved with the highest forward speed, separately scalper and steel hollow, and lowest of sugar yield obtained at the highest forward speed of $(7.1 \mathrm{~km} / \mathrm{h})$, connected of scalper and pot and rubber track that achieved the minimum crowns scalping this may be due to increment of nitrate which led to decrement of sugar yield. At the same time, in fig. (6) noticed that the intersection between two curves that represent the yield of sugar beet and sugar ratio at the four levels of forward speed of $(4.5,5.2,6$ and $7.1 \mathrm{~km} / \mathrm{h})$, with fixed type of scalper at (separately scalper) and type of caliper (steel hollow). At the same time, drawn data in mentioned figures caused flow curves (descending) with sugar yield while caused ascending curve with beet yield, this meant that there was an indirect relationship between beet yield and forward speed and an indirect proportional between sugar ratio and forward speed. This indicates that optimum type of scalper was the (separately scalper) and type of caliper ( steel hollow). These optimum factors may be attributed to the excessive fixed of the scalper on the top of ridge led to increasing of scalping crowns. So the forward speed of 5.2 $\mathrm{km} / \mathrm{h}$, separately scalper and steel hollow are recommended for increasing the total root and sugar yield.

\section{The energy requirement for the scalper at different forward speeds using different types of scalper and caliper .}

The represented data in Table (2) indicated that for both type of separately scalper and type of steel hollow caliper (for sugar beet, Esperanza). It can be easily noticed that scalper affected deeply on the energy requirement at constant forward speed. The results showed that the increasing of forward speed resulted in decreasing the energy requirement $(\mathrm{kW} . \mathrm{h} / \mathrm{fed}$.). It was found that increasing forward speed from 4.5 to $7.1 \mathrm{~km} / \mathrm{h}$ resulted in decreasing energy requirement (kW.h/fed.) from 15.57 to 11.26 (kW.h/fed). The same trend was shown with forward speed of 5.2 and $6 \mathrm{~km} / \mathrm{h}$. From Table (2), it was clear that the energy requirement was lower with separately scalper and steel hollow caliper than other factors. 


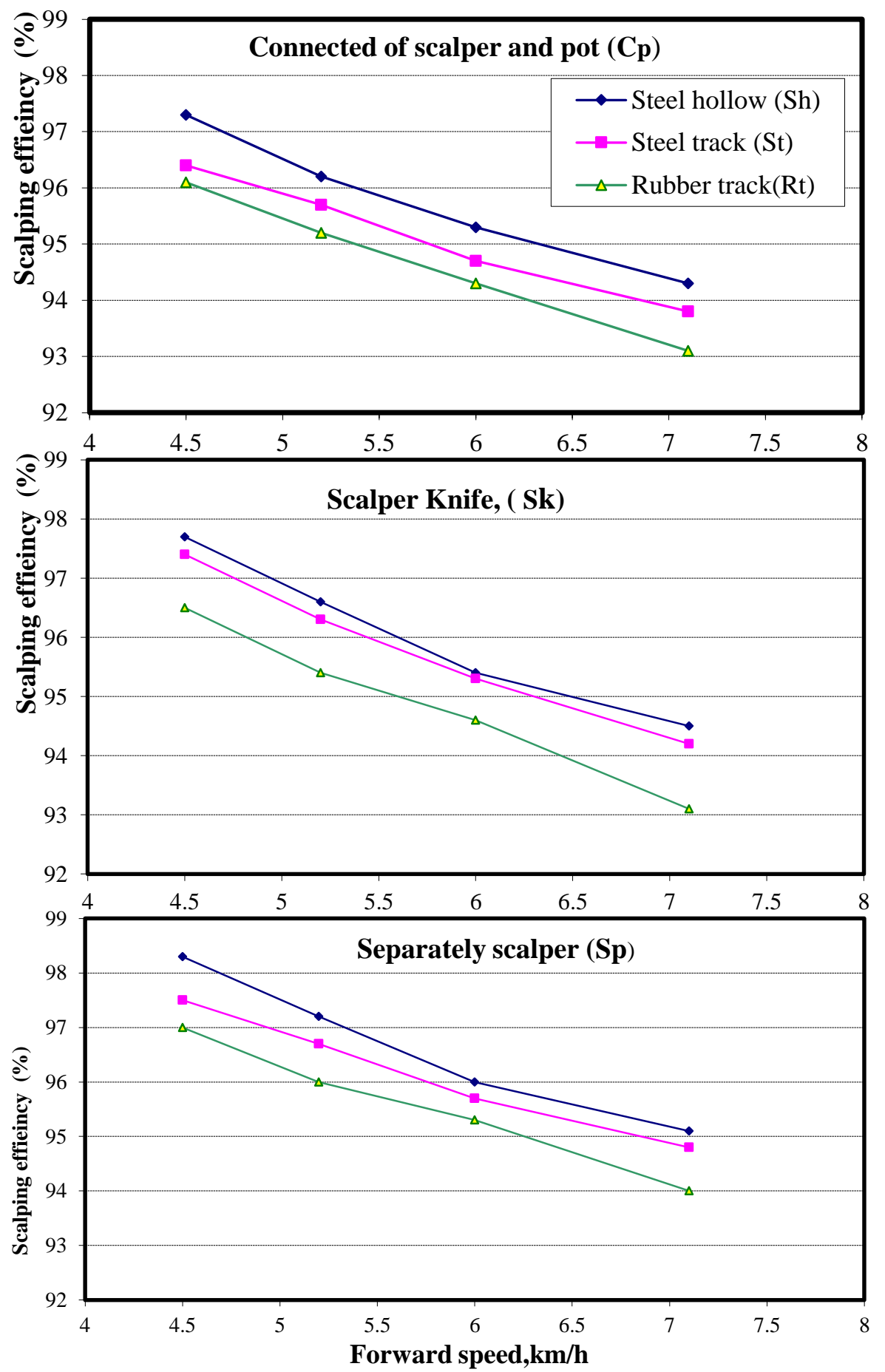

Fig.(3):Effect of scalper and caliper types on the scalping efficiency for the sugar beet at different forward speeds . 

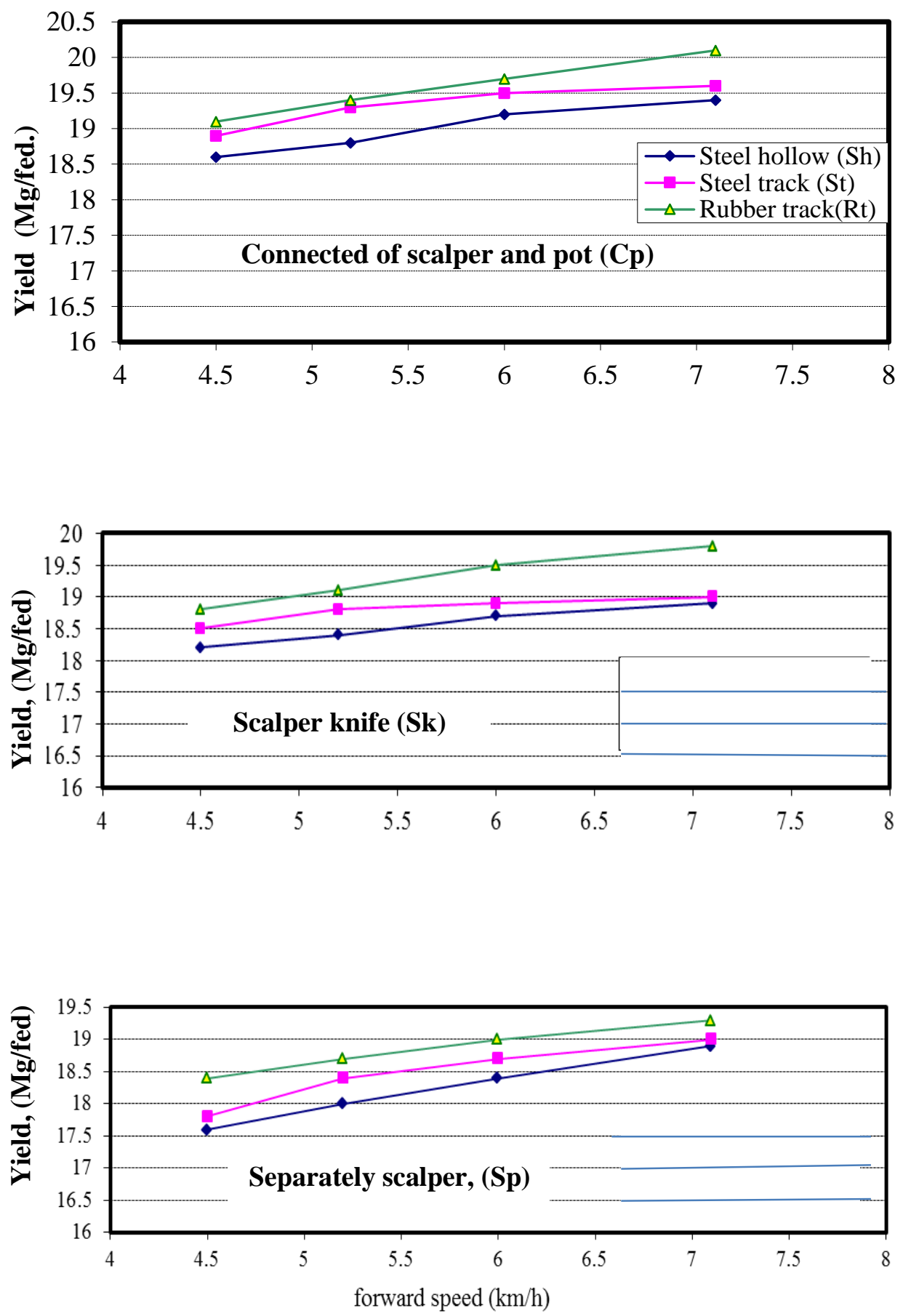

Fig.(4):Effect of scalper and caliper types on the sugar beet yield at different forward speeds . 

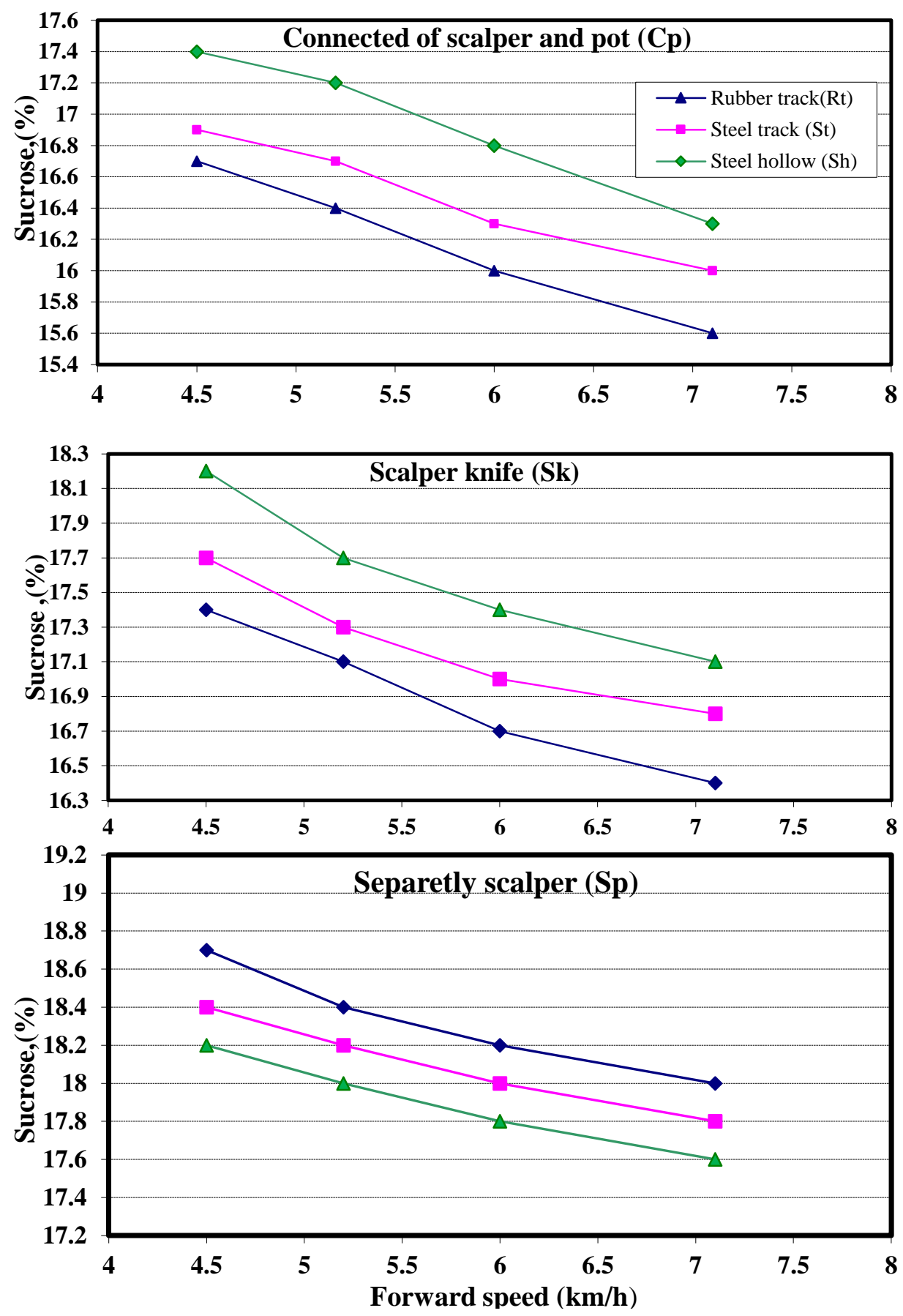

Fig.(5):Effect of scalper and caliper types on the sucrose percentage at different forward speeds . 


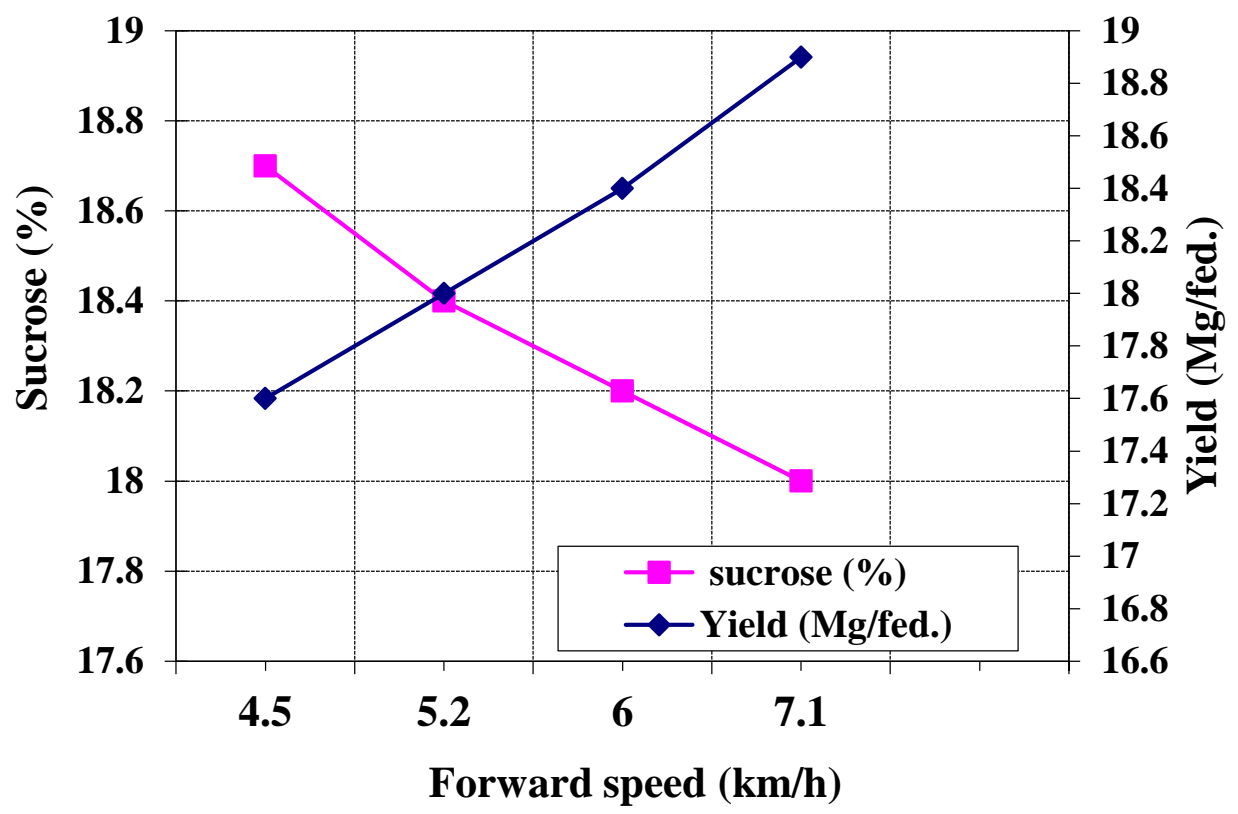

Fig. (6): The proper forward speed that achieved the optimum values for sucrose and yield.

Table (2): Effect of studied factors on machine field capacity (fed/h), power requirement, $(\mathrm{kW})$ and energy requirement $(\mathrm{kW} . \mathrm{h} / \mathrm{fed}$.) for the tested scalper.

\begin{tabular}{|c|c|c|c|c|c|c|c|c|c|c|c|c|}
\hline \multirow{3}{*}{$\begin{array}{c}\text { Type of } \\
\text { scalper (Ts) }\end{array}$} & \multicolumn{4}{|c|}{ Field capacity (fed./h) } & \multicolumn{4}{|c|}{ Power requirement $(\mathrm{kW})$} & \multicolumn{4}{|c|}{$\begin{array}{c}\text { Energy requirement } \\
\text { (kW.h/fed.) }\end{array}$} \\
\hline & \multicolumn{4}{|c|}{ Forward speed ,km/h } & \multicolumn{4}{|c|}{ Forward speed ,km/h } & \multicolumn{4}{|c|}{ Forward speed, km/h } \\
\hline & 4.5 & 5.2 & 6 & 7.1 & 4.5 & 5.2 & 6 & 7.1 & 4.5 & 5.2 & 6 & 7.1 \\
\hline separately & 2.03 & 2.34 & 2.7 & 3.2 & 31.60 & 32.86 & 34.44 & 36.02 & $\mathbf{1 5 . 5 7}$ & 14.04 & 12.76 & 11.26 \\
\hline knife & 2.08 & 2.41 & 2.78 & 3.29 & 33.05 & 36.02 & 37.60 & 39.50 & 15.89 & 14.95 & 13.53 & 12.01 \\
\hline connected & 2.17 & 2.51 & 2.89 & 3.42 & 34.57 & 37.60 & 39.18 & 41.71 & 15.93 & 14.98 & 13.56 & 12.20 \\
\hline
\end{tabular}

The highest value of energy requirement of $15.93 \mathrm{~kW} . \mathrm{h} / \mathrm{fed}$ with steel hollow caliper was obtained at forward speed of $4.5 \mathrm{~km} / \mathrm{h}$ and connected scalper with pot while the lowest value of energy requirement under the same conditions was ( $11.26 \mathrm{~kW} . \mathrm{h} / \mathrm{fed}$.) at forward speed of $7.1 \mathrm{~km} / \mathrm{h}$, 
steel hollow caliper and separately scalper. Data analyzed showed that there was a significant effect for using scalper $(\mathrm{p}<0.01)$ under the same conditions of forward speed, scalper and caliper systems. Also, there was a significant effect by decreasing forward speed from 7.1 to $4.5 \mathrm{~km} / \mathrm{h}$.

\section{CONCLUSION}

It was found that using the tested scalper with steel hollow caliper and separately disk razor hydraulically driven under forward speed of 5.2 $\mathrm{km} / \mathrm{h}$ gave the best results in all treatments.

\section{REFERENCES}

Abd - Rabou, A.F. (2004) Manufacturing a small machine to suit harvesting sugar beet under Egyptian conditions. PhD Thesis. Agric. Mech. Dept., Fac. Agric., Kafr El-Sheikh. Tanta Univ.,Egypt, 33$131 \mathrm{PP}$.

Cole, D. F. and G. J. Seiler (1996) Effect of Crown Material on Yield and Quality of Sugar Beet Roots: A Grower Survey1" Cooperative investigation of the Agricultural Research Service. U.S. Department of Agriculture, and the Agricultural Experiment Station, North Dakota State University. Fargo, ND 58102. Published as Journal Paper No. 727. 'Research Plant Physiologist and Research Technician.

El-Shabrawy, H. ;R.G. Salim, and R. R. Barakat (2014) Performance evaluation of sugar beet two split harvesters under Egyptian conditions. Misr. J. Agric., 10 (2): 190-206.

Grimme hand book (2009) “ operation manual leaf mulcher BM300" Grimme, Landmashchinenfabrik GmbH \&Co. KG. Hunteburger Str., 32, 49401 Damme, Germany. 
Jaggard, K.W.; C.J.A. Clark and A.P. Draycott. (1999) The weight and processing quality of components of storage roots of sugar beet (Beta vulgaris L). J Sci. Food Agric., 79:1389-1398 PP.

Kromer, K.H.; M. Thelen and P . Degen. (1998) States of sugar beet harvesting in Europe: comparison of harvesting systems Germany ,123(10) : 816-821.

\section{الملخص العربيى}

دراسات هندسية على كاشطات قمة الجذور الملحقة بمحشة بنجر السكر

$$
\text { د. رضا جمعه سالم** و د. حنان الشال*** }
$$

يعتبر محصول بنجر السكر من أهم المحاصيل الإقتصادية فى مصرحيث يمكن زر اعته فى مختلف أنو اع الأراضى ونظر اً لتكلفة عملية الحصاد اليدوى الكبيرة تم تعديم الميكنة الكاملة له له فى الأراضى الجديدة وتطلب مصانع السكر بمر من المستثرين ضرورة إستعمال جهاز

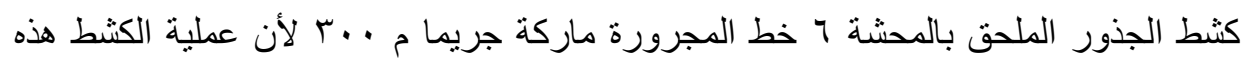
تقلل نسبة النترات و الثو ائب التى تتسبب زيادتها فى قلة نسبة السكر بالمحصول الناتج مما يقلل القيمة المالية للمنتج حيث ان منطقة التاج هذه وجودها يزيد الإنتاجية قليلا ويقلل نسبة السكر ومن المعلوم ان مصانع السكر تمنح علاوة 25 جنيه عن كل (\% زيادة فى نسبة السكر وكذلك هناك علاوة نظافة والوجدة الملحقة بالمحشة لكثط الجذزر تحقق زيادة نسبة السكر وتقلل الثو ائب ممايزيد من سعر المنتج ويحفز المزارع لذا كان الهدف من هذا البحث: ا ـ تحديد العوامل الهندسية المنلى لتشغيل كاثطة قمة جذور البنجر.

r. دراسة تأثير كثط قمة الجذور على كفاءة تشغيل الالة و إنتاجية البنجر ونسبة السكر r. تقديم التوصيات بالعو امل التشغيلية المثلى للشركات الإستثمارية المستوردة لهذه الكاشطات بغرض رفع القيمة التسويقية لبنجر السكر. بلئر

* باحث بمعهد بحوث الهندسة الزراعية ـ الجيزة - مصر.

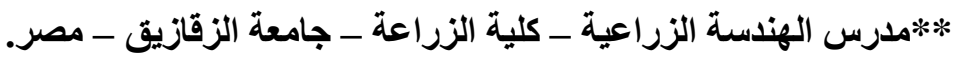


أُجريت التجارب فى مزارع شركة النوران للزر اعه المتقدمة - محافظة الشرقية على مساحة

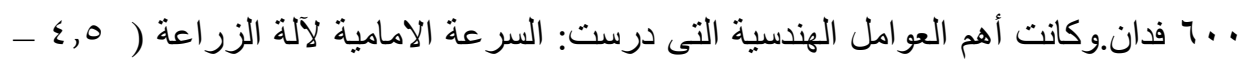

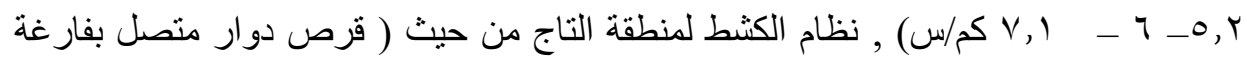
الموتور الهيدروليك - قرص دوار منفصل عن الفارغة - سكينة قاطعه). نوع حساس القطع من حيث ( الكاوتشوك ـ الصلب المصمت ـ الصلب المجوف). وتم تثبيت عو امل أخرى مثل ز اوية القطع للقرص الدوار (.1 درجات على الأفقى) و سرعة عمود الإدارة الخلفى (.... لفة/دقيقة) ـ كما تم قياس كل من كفاءة عملية الكثط و إنتاجية بنجر السكر ونسبة السكر والطاقة المسترهة.

\section{النتائج والتوصيات التطبيقية:}

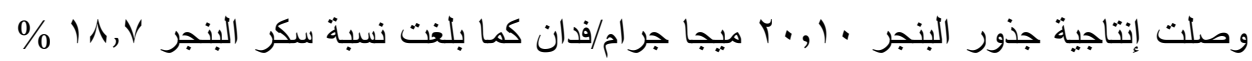
بمعدل ه, \م ميجاجرام/فدان. كما وجد أن افضل العوامل التشغيلية للالة المطورة استخدام سرعة امامية ب, 0 كم/س قرص دوار منفصل عن الفارغة وحساس من الصلب المجوف

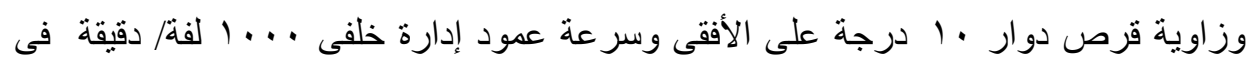

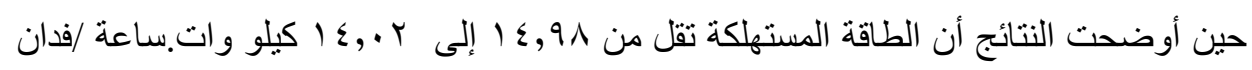

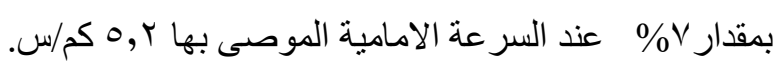

